\title{
Jambolan sherbets overrun, color, and acceptance in relation to the sugar, milk, and pulp contents in formulation
}

\author{
Jackeline Cintra SOARES ${ }^{1}$, Marina Costa GARCIA ${ }^{1}$, Lismaíra Gonçalves Caixeta GARCIA ${ }^{1}$, Márcio CALIARI ${ }^{1 *}$, \\ Manoel Soares SOARES JÚNIOR ${ }^{1}$
}

\begin{abstract}
The aim of this study was to evaluate in sherbet formation the effects of sugar, milk, and jambolan pulp quantity on the overrun, color, physicochemical characteristics, microbiological characteristics, and acceptance of the experimental sherbets, in addition to evaluating the bioactive compounds of the selected product. Seven formulations were established through the Simplex

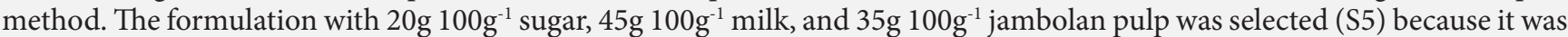
included among the most accepted sensorially (S4 and S5), and also presented higher overrun, chroma, SST/AT, and pH than S4, receiving the scores 8.0; 8.2, 6.4 and 7.1 and 6.1, respectively, for appearance, color, flavor, texture, and odor. The selected sherbet presented a high total phenolic compound content of $192 \mathrm{mg}$ gallic acid $\mathrm{g}^{-1}$, and a percentage of DPPH inhibition of $73 \%$. It is concluded that it is possible to produce jambolan sherbet with desirable physical, chemical, microbiological, and sensory characteristics, which can increase the possibilities of applying the fruit as an ingredient in the edible ice cream industry.
\end{abstract}

Keywords: edible ice creams; simplex method; total phenolic compounds; antioxidant activity.

Practical Application: Use the jambolan fruit as an ingredient in the edible ice cream industry.

\section{Introduction}

Jambolan (Syzygiumcumini) fruit has been wasted in great amounts, due to the high production per tree, short shelf life of the fruit in natura, and mainly because of the lack of options to use it in the food industry (Lago et al., 2006). Few studies relate applications of the processed fruit, among them dehydrated jambolan pulp in a spouted bed dryer (Mussi et al., 2015), jambolan wine (Bezerra et al., 2015), and mixtures of pear juice with jambolan (Kapoor \& Ranote, 2015). Jambolan presents great potential to be used in the edible ice cream line, mainly in relation to the intense purple color, due to its epicarp being rich in anthocyanins. The pulp has high antioxidant activity (Reynertson et al., 2008). Similar to ice cream, sherbet is usually processed with a higher quantity of fruit pulp and lower quantity of milk.

In general, sherbets present less overrun, or less air incorporation ( $25 \%$ to $50 \%)$, higher sugar content, lower melting point, and coarser texture than ice cream (Marshall \& Arbuckle, 1996). During formulation, the milk fat influences the texture, body, and decreased sensation of cold, while the proteins improve the structure, interfere with emulsification and mixing time. The added sucrose and the glucose from the fruit pulp itself contribute to increasing viscosity, decreasing the freezing point, increasing flavor, and fixating aromatic compounds. The stabilizers improve the stability of the emulsion and the body, decrease melting speed, and influence the speed and melting temperature of the mixture (Oliveira et al., 2005).
Due to the lack of information related to jambolan sherbets, the present study aimed to evaluate the effects of sucrose, milk, and jambolan pulp quantities in the formulation regarding overrun, instrumental color, microbiological risk, and sensory acceptance, in addition to bioactive compounds (total phenolic compounds, anthocyanins, and hydrolyzed and condensed tannins) and antioxidant activity of the selected jambolan sherbet.

\section{Materials and methods}

\subsection{Collection and treatment of raw material}

The fruits were harvested from adult plants, in the city Goiânia, from January to March of 2014, at the maturation stage suitable for consumption. Therefore, the tree branches were shaken and the ripe fruits fell into a canvas, which was stretched out below the branches in order to avoid the contact of the fruits with the soil. The fruits were packed in low density polyethylene (LDPE) bags and expanded polystyrene boxes, and transported to the Plant Products Processing Plant. After selection, which eliminated damaged fruit attacked by diseases and rot, the chosen fruits were washed with tap water, sanitized in sodium hypochlorite solution ( $\left.200 \mathrm{mg} \mathrm{L}^{-1}\right)$ for $20 \mathrm{~min}$, dried at a temperature of $25^{\circ} \mathrm{C}$, and mechanically depulped (Itametal, 025 DF A8, Itabuna, Brazil). Portions of $1 \mathrm{~kg}$ of jambolan pulp were packed in LDPE bags, frozen, and stored at $-18{ }^{\circ} \mathrm{C}$. 


\subsection{Sherbet processing (experimental design)}

For the sherbet production, $\operatorname{crystal}$ sugar $\left(\mathrm{Cristal}^{\circledR}\right)$, pasteurized milk (Vitalac ${ }^{\circledR}$ ), neutral alloy neutral mix Pro Sorvete ${ }^{\circledR}$ (sugar, guar gum, and starch), and emulsifier $\left(\right.$ Biomix $^{\circledR}$ ) were used, acquired in the local store (Goiânia, GO), in addition to the frozen pulp of the processed jambolan.

The maximum and minimum levels of the variable components of the mixtures used in the sherbet formulations were pre-established sensorially by the researchers involved. By using the Simplex method (Box et al., 2005), and the software Statistica 7.0 (Statsoft, version 7.0, Tulsa, USA), seven mixtures and two replicates of the central point were established. The values in pseudocomponents were established by the proportion ranges of the ingredients (Table 1).

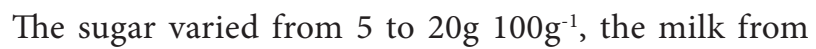

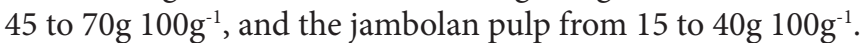
To add the fixed ingredients neutral alloy $\left(0.7 \mathrm{~g}_{\left.100 \mathrm{~g}^{-1}\right) \text { and }}\right.$

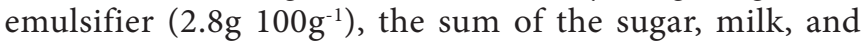

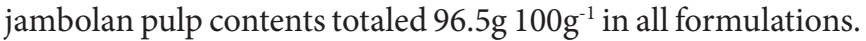
The jambolan pulp was thawed, and at $25^{\circ} \mathrm{C}$ was homogenized with the other ingredients in an industrial blender (Siemsen, D560484, Jaraguá do Sul, Brazil). Soon after, the mixture was placed in a dough kneading machine (Everest, Horizontal type, São Carlos, Brazil) for air incorporation, at a temperature of $-7^{\circ} \mathrm{C}$ for $4 \mathrm{~min}$. The experimental sherbets were placed in $2 \mathrm{~L}$ highdensity polyethylene (HDPE) packages with lids, and stored at $-18^{\circ} \mathrm{C}$.

The effects of the sugar, milk, and jambolan pulp concentrations on overrun, chroma, hue angle, total soluble solids ratio (TSS)/total acidity (TA), pH, microbilogical risk, and sensory acceptance of the sherbets were determined. Some bioactive compounds, such as anthocyanin, hydrolyzed and condensed tannin, and total phenolic compound contents, was also determined in the selected sherbet, in addition to antioxidant capacity in aqueous and ethanolic extracts.

\subsection{Overrun, color, TSS/TA, and $p H$}

The overrun was determined according to the method described by Martinou-Voulasiki \& Zerfiridis (1990). The color parameters were obtained through a colorimeter (Hunter-Lab,

Table 1. Real proportion and pseudocomponents of sugar, milk, and jambolan pulp in experimental sherbets.

\begin{tabular}{clllllll}
\hline \multirow{2}{*}{ Formulation } & \multicolumn{3}{c}{ Real proportion } & & \multicolumn{3}{c}{ Pseudocomponents } \\
\cline { 2 - 3 } \cline { 6 - 7 } & Sugar & Milk & Pulp & & $\begin{array}{c}\text { Sugar } \\
\left(\mathrm{x}_{1}\right)^{1}\end{array}$ & $\begin{array}{c}\text { Milk } \\
\left(\mathrm{x}_{2}\right)\end{array}$ & $\begin{array}{c}\text { Pulp } \\
\left(\mathrm{x}_{3}\right)\end{array}$ \\
\hline S1 (A) & 0.134 & 0.583 & 0.283 & & 0.24 & 0.38 & 0.38 \\
S1 (B) & 0.134 & 0.583 & 0.283 & & 0.24 & 0.38 & 0.38 \\
S1 (C) & 0.134 & 0.583 & 0.283 & & 0.24 & 0.38 & 0.38 \\
S2 & 0.15 & 0.70 & 0.15 & & 0.29 & 0.71 & 0 \\
S3 & 0.2 & 0.65 & 0.15 & & 0.43 & 0.57 & 0 \\
S4 & 0.2 & 0.45 & 0.35 & & 0.43 & 0 & 0.57 \\
S5 & 0.15 & 0.45 & 0.40 & & 0.29 & 0 & 0.71 \\
S6 & 0.05 & 0.70 & 0.25 & & 0 & 0.71 & 0.29 \\
S7 & 0.05 & 0.55 & 0.40 & & 0 & 0.29 & 0.71 \\
\hline
\end{tabular}

${ }^{1} \mathrm{X}_{1}+\mathrm{X}_{2}+\mathrm{X}_{3}=1$ or $100 \% ; \mathrm{A}, \mathrm{B}$, and $\mathrm{C}$ are replicates of the same formulation (central point).
Color Quest II, Reston, USA). The values $\mathrm{a}^{*}$ and $\mathrm{b}^{*}$ were used to calculate the chroma and the hue angle. The $\mathrm{pH}$ was measured using a potentiometer (Tecnal, TEC-51, Piracicaba, Brazil). Titratable acidity (TA) was obtained through titration with $\mathrm{NaOH} 0.1 \mathrm{~N}$ solution and total soluble solids (TSS) content using a digital refractometer (Reichert, $\mathrm{R}^{2}$ mini, New York, USA), to calculate the TSS/TA ratio. All analyses were performed in triplicate, according to the norms of the Association of Official Analytical Chemists (1997).

\subsection{Microbiological risk}

Coliform count at $45^{\circ} \mathrm{C}$, Estafilococos coagulasepositiva, and Salmonella were performed according to the American Public Health Association (2001).

\subsection{Sensory acceptance}

The attributes evaluated were appearance, color, flavor, odor, and texture, using a hedonic scale of nine points $(9-$ like extremely, 5 - neither like nor dislike, and 1 - dislike extremely), and randomized block design (Stone \& Sidel, 2004). The product was considered accepted when the average score surpassed six (6). Fifty adult consumers of both sexes were recruited according to their interest in participating in the research. The test was performed in a sensory analysis laboratory, and the samples were served in monadic sequential form, in individual cabins under white light. This research project was approved by the Ethics Committee under protocol number 25778613.0.0000.5083.

\subsection{Bioactive compounds and antioxidant activity}

The total phenolic compound contents were determined by spectrophotometry (Biotech Pharmacy, Ultrospec 2.000 UV/Visible, Ultrospec 2.000 UV/Visible, Cambridge, England), at 740nm, using the Folin-Ciocalteau reagent, and the data obtained were expressed in mg of gallic acid per $\mathrm{g}$ of sample (Waterhouse, 2002). Free radical-scavenging activity was measured using a method adapted by Brand-Williams et al. (1995). In brief, $50 \mu \mathrm{L}$ of crude extract in different concentrations $\left(0.09-100 \mathrm{mg} \mathrm{mL}^{-1}\right)$ was mixed with $250 \mu \mathrm{L}$ of DPPH $\left(0.004 \% \mathrm{w} \mathrm{v}^{-1}\right)$. After $30 \mathrm{~min}$ of the reaction, the absorbance of the remaining DPPH was measured at $517 \mathrm{~nm}$ against blank. Antioxidant activity was expressed as a percentage of the absorbance of the control DPPH solution, obtained from the following Equation 1:

$$
\text { Activity } \left.=\left[\left(A_{D P P H}-A_{E x t r}\right) A_{D P P H}^{-1}\right)\right] \times 100
$$

where $A_{D P P H}$ is the absorbance value of the $\mathrm{DPPH}_{\text {blank }}$ sample, and $A_{\text {Extr }}$ is the absorbance value of the test solution.

$A_{\text {Extr }}$ was evaluated as the difference between the absorbance value of the test solution and the absorbance value of its blank. The total anthocyanin content was estimated by spectrophotometry. For the extraction of anthocyanin compounds, $1 \mathrm{~g}$ of sample was used, with the addition of $25 \mathrm{~mL}$ of ethanol solution $\mathrm{pH} 1.0$, which incubated for $1 \mathrm{~h}$ at room temperature, and afterwards the reading was taken at a wavelength of $520 \mathrm{~nm}$. The results were expressed in mg of cyanidin-3-glycoside $100 \mathrm{~g}^{-1}$ (Barcia et al., 
2012). The total condensed tannins content was estimated by colorimetry, according to the Price et al. (1978), whose quantification was based on establishing a standard catechin curve with 600 to $1200 \mathrm{mg} \mathrm{L}^{-1}$. The results were expressed in $\mathrm{g}$ of equivalent catechin per $100 \mathrm{~g}$ of sample. The hydrolized tannins content was also estimated by colorimetry (Brune et al., 1991), at $680 \mathrm{~nm}$ wavelength (blue), using methanol to zero the equipment (white). The quantification was based on establishing a standard curve of gallic acid with 1 to $140 \mathrm{mg} \mathrm{L}^{-1}$. The data were expressed in $\mathrm{mg}$ of equivalent gallic acid per $100 \mathrm{~g}$ of sample.

\subsection{Statistical analysis}

Polynomial models were fitted to each response, and numeric coefficients were estimated through Scheffé canonical models. These models were subjected to analysis of variance (ANOVA), and the level of significance, coefficient of determination $\left(\mathrm{R}^{2}\right)$, and lack of adjustment (LA) of the models were obtained. The models were validated, in an assay with three original replicates, and analyses in triplicate. The sensory score averages were compared using the Tukey test at $5 \%$.

\section{Results and discussion}

\subsection{Overrun, instrumental color, TSS/TA, and $p H$}

The models for overrun, chroma, hue angle, $\mathrm{pH}$, and TSS/TA were significant at $5 \%$ probability and explained 82 to $99 \%$ of the responses (Table 2). The lack of adjustment was significant only for the overrun model, but because the pure average square error was very low in comparison to the total errors, the lack of adjustment was considered irrelevant. Therefore, all models were considered predictive.

For overrun, chroma, hue angle, and TSS/TA the interactions effects were not significant. The diagram of triangular level curves was obtained from the adjusted model for overrun (Figure 1).
The greatest air incorporation (higher sherbet yield) can be observed within the graphic area between the points 2,C, D

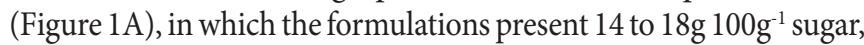

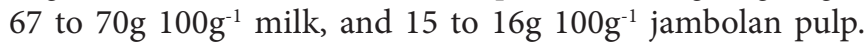
Air incorporation is related to higher milk fat contents in the formulations. The air is dispersed through the fat-matrix emulsion, and the quantity is very important for the quality, because it makes the product softer (Marshall et al., 2003). In addition to enhancing the perception of flavors, the sugars contribute to decreasing the hardness, since they act as antifreeze, or in other words, decrease the mixture freezing point (Fanin \& Saracchi, 2006), increasing air incorporation and causing higher creaminess. These aspects were also observed in the present study.

The lowest percentage of air incorporation was found in the region between points $5, \mathrm{~A}, \mathrm{~B}$, in which the sugar contents varied

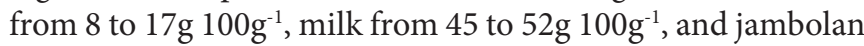
pulp from 38 to $40 \mathrm{~g}^{100 \mathrm{~g}^{-1}}$. Increased jambolan pulp concentration (fiber source) decreased air incorporation, probably due to the reduced $\mathrm{pH}$ of the sherbets (Figure 1E), which affected emulsion stability. Oliveira et al. (2005) studied the physical properties of mango sherbet mixture and obtained 20.01 to $40.59 \%$ air incorporation; in this study the air incorporation was similar and varied from 16.70 to $39.87 \%$.

The jambolan sherbets chroma varied from 5.63 to 22.88 (Figure 1B), and the sugar did not present significant effect for this color parameter. The sherbets with higher color saturation, better suited for the consumer, were obtained in the area between points $7 \mathrm{~A}$, and $\mathrm{B}$, with sugar contents varying from

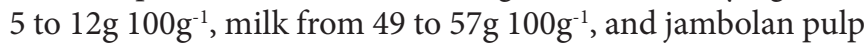

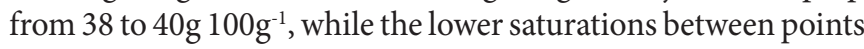
2 and 3 . The sherbets in area at point $C$ had sugar contents from

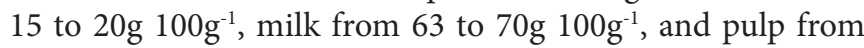

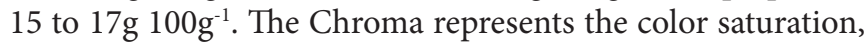
or in other words, it indicates the color purity or intensity in

Table 2. Polynomial models, lack of adjustment (PA), level of significance (p) and coefficient of determination $\left(\mathrm{R}^{2}\right)$ for $(\%)$, chroma ( $\left.\mathrm{c}^{\star}\right), \mathrm{H}(\mathrm{degrees})$, $\mathrm{pH}$, and TSS/TA ratio of the sherbets in relation to the pseudocomponents sugar $\left(\mathrm{x}_{1}\right)$, milk $\left(\mathrm{x}_{2}\right)$ and jambolan pulp $\left(\mathrm{x}_{3}\right)$.

\begin{tabular}{ccccc}
\hline Property & Model & $\mathrm{p}$ & $\mathrm{PA}$ & $\mathrm{R}^{2}$ \\
\hline Overrun & $\mathrm{y}=34.27 \mathrm{x}_{1}+42.04 \mathrm{x}_{2}+10.66 \mathrm{x}_{3}$ & 0.00 & 0.01 & 0.93 \\
Chroma & $\mathrm{y}=0.89 \mathrm{x}_{1}{ }^{\text {ns }}+7.78 \mathrm{x}_{2}+28.56 \mathrm{x}_{3}$ & 0.00 & 0.29 & 0.81 \\
Hue Angle & $\mathrm{y}=312.19 \mathrm{x}_{1}+297.37 \mathrm{x}_{2}+308.20 \mathrm{x}_{3}$ & 0.01 & 0.57 & 0.92 \\
$\mathrm{pH}$ & $\mathrm{y}=6.25 \mathrm{x}_{1}+6.54 \mathrm{x}_{2}+4.93 \mathrm{x}_{3}+1.17 \mathrm{x}_{1} \mathrm{x}_{2}+1.08 \mathrm{x}_{2} \mathrm{x}_{3}$ & 0.00 & 0.99 & 0.28 \\
TSS/TA & $\mathrm{y}=4.34 \mathrm{x}_{1}+2.51 \mathrm{x}_{2}+0.26 \mathrm{x}_{3}{ }^{\mathrm{ns}}$ & 0.00 & 0.93 \\
\hline
\end{tabular}

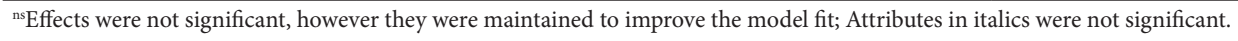
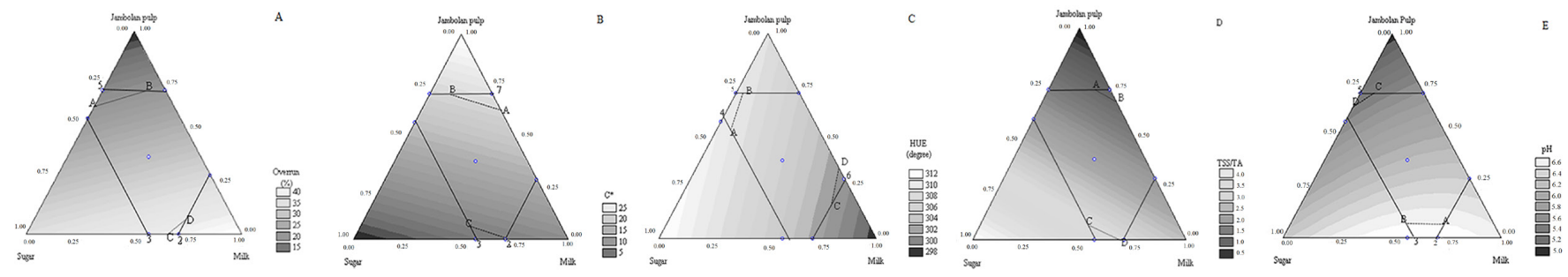

Figure 1. Overrun (A), chroma $\left(\mathrm{c}^{\star}\right)(\mathrm{B})$, hue angle $(\mathrm{H})(\mathrm{C})$, TSS/TA ratio (D), and $\mathrm{pH}(\mathrm{E})$ in relation to sugar, milk, and jambolan pulp contents (in pseudocomponents). Area demarcated between the numbered points demonstrate the experimental space analyzed. 
relation to white. The jambolan sherbets showed high degrees of saturation, or in other words, coloration considered pure and vivid.

Tonality values varied from 299.47 to $310.05^{\circ}$. The hue degree $\left(\mathrm{H}^{*}\right)$ indicates product tonality: close to $0^{\circ}$ or $360^{\circ}$ is red; $90^{\circ}$ yellow, $180^{\circ}$ green, and $270^{\circ}$ blue. The highest $\mathrm{H}^{*}$ values, which are more appropriate for sherbet coloration, were found in the triangular diagram area between the points 4,5,A, and B (Figure 1C), in

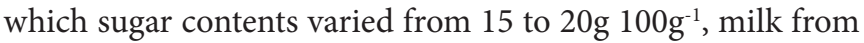

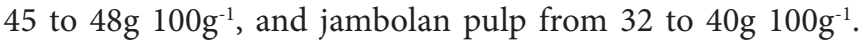
The lowest $\mathrm{H}^{*}$ values were between the points 6 , C, and $\mathrm{D}$, with

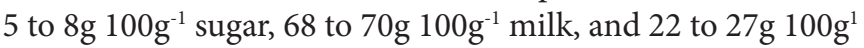
jambolan pulp. The sherbet color tones were between red and blue, which were minimally influenced by the sugar contents, intermediately influenced by the milk, and strongly influenced by the jambolan pulp, due to its richness in anthocyanic compounds, which present intense tones between red and blue (Ayyanar \& Subash-Babu, 2012). The $\mathrm{pH}$ is the factor that most influences anthocyanin coloration, which, depending on the acidity or alkalinity, may present different structures (Lee et al., 2005). In basic $\mathrm{pH}$, anthocyanins present blue coloration, while in acidic $\mathrm{pH}$, they present purple coloration; therefore in the formulations with higher milk contents, the medium was more basic and tended to show a bluer tonality.

The TSS/TA ratio is an indicator used to determine the sweet/acid flavor balance (Couto \& Canniatti-Brazaca, 2010). The higher TSS/TA values of the experimental sherbets were found in the graphic area between the points $3, \mathrm{C}$, and D

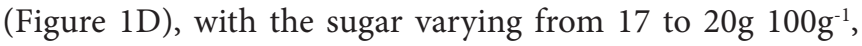
the milk from 61 to $68 \mathrm{~g} 100 \mathrm{~g}^{-1}$, and the jambolan pulp from

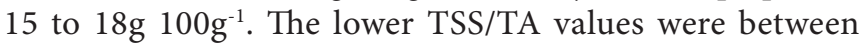

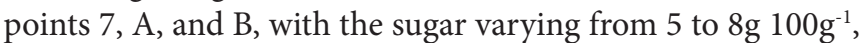

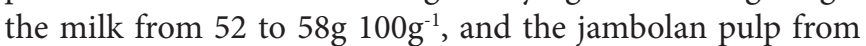

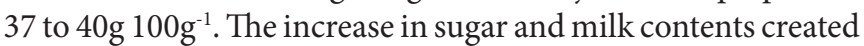
a positive effect in the TSS/TA ratio, since sucrose and lactose add more sweetness to the product. In contrast, the jambolan pulp negatively interfered with the TSS/TA ratio, because the pulp possesses acidic characteristics (Figure 1D).

The highest $\mathrm{pH}$ values within the studied area were found between points 2, 3, A, and B (Figure 1E), or in other words

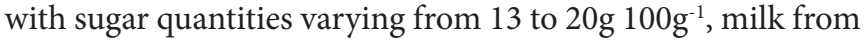

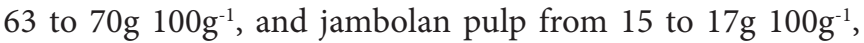
and the lowest $\mathrm{pH}$ values were between points $5, \mathrm{C}$, and $\mathrm{D}$, in

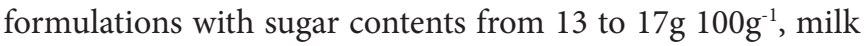

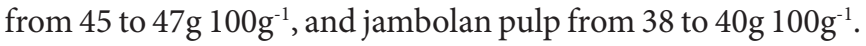
Jambolan pulp, like most fruits, has an acidic character since it is contains organic acids. Therefore, the higher the jambolan pulp concentration in the formulation, the higher the quantity of acids present, which decreases the $\mathrm{pH}$ of the final product. The jambolan pulp pH was found to be about 3.9 (Lago et al., 2006), while the milk pH was around 6.4 to 6.8 (Fagnani et al., 2017). Therefore, the jambolan sherbets formulated with higher milk contents and lower pulp contents presented higher $\mathrm{pH}$ values. Increasing the sugar in the formulations decreases the acidity of the medium, causing an increase in $\mathrm{pH}$ value.

\subsection{Microbiological risk}

Counts lower than $10 \mathrm{UFC} \mathrm{g}^{-1}$ were obtained in the experimental sherbets for coliforms at $45^{\circ} \mathrm{C}$ and estafilococos coagulase positiva, while for Salmonela, absence was verified in $25 \mathrm{~g}$ of sample. The microbiological analysis of the jambolan sherbets demonstrated that they all had microbiological standards in accordance with the adequate quality of raw materials and good manufacturing practices.

\subsection{Sensory acceptance}

The appearance and color of all the sherbets were accepted by the tasters, receiving scores above 6.0 (like slightly). The sherbets S1, S4, and S5 received the highest scores, which did not differ among themselves (Table 3).

Regarding the flavor, S2, S3, S4, and S5 had the highest scores, since they contain the highest sugar contents, and the formulations with lower sugar contents $\left(5 \mathrm{~g} 100 \mathrm{~g}^{-1}\right)$ were not accepted by the consumers. Brazilian consumers prefer sweeter flavors (Hansen et al., 2008). In regard to the texture, the formulations S1, S2, S3, S4, and S5 obtained scores above 7.0 and differed from S6 and S7, due to

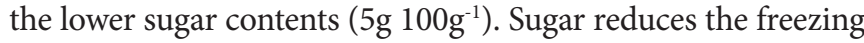
point of the water, causing ice crystal formation, which affords less creaminess (Cook \& Hartel, 2010). The formulations with

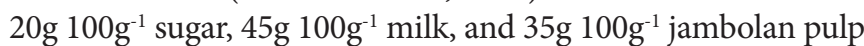
(S5) were selected, since they were among the most sensorially accepted (S4 and S5) and also showed higher overrun, color intensity, TSS/TA ratio, and $\mathrm{pH}$ than S4.

\subsection{Model validation with the selected sherbet}

It can be affirmed that the predicted model corroborated with the values found analytically; in other words, a mixture of sugar, milk, and jambolan pulp with characteristics similar to those predicted by the models was obtained, with variation percentages of $46 \%$ for overrun, $15.6 \%$ for chroma, $1.7 \%$ for hue angle, $23 \%$ for TSS/TA ratio, and $81 \%$ for $\mathrm{pH}$. The differences between the analyzed and calculated values are related to experimental errors and to the coefficient of determination of the equations.

\subsection{Anthocyanins, tannins, phenolic compounds, and antioxidant activity}

The total phenolic compound content, observed in the selected sherbet (Table 4), was higher than that found in crude European blueberry extract, obtained by Yi et al. (2006) which varied from

Table 3. Average scores obtained by the experimental jambolan sherbets.

\begin{tabular}{cccccccc}
\hline Attribute & \multicolumn{1}{c}{$\mathrm{S} 1^{1}$} & $\mathrm{~S} 2$ & $\mathrm{~S} 3$ & $\mathrm{~S} 4$ & $\mathrm{~S} 5$ & $\mathrm{~S} 6$ & $\mathrm{~S} 7$ \\
\hline Appearance & $7.7^{\mathrm{AB}}$ & $6.9^{\mathrm{BC}}$ & $7.5^{\mathrm{ABC}}$ & $7.9^{\mathrm{A}}$ & $8.0^{\mathrm{A}}$ & $6.1^{\mathrm{D}}$ & $6.8^{\mathrm{CD}}$ \\
Color & $7.9^{\mathrm{AB}}$ & $6.6^{\mathrm{CD}}$ & $7.1^{\mathrm{BCD}}$ & $7.8^{\mathrm{AB}}$ & $8.2^{\mathrm{A}}$ & $6.3^{\mathrm{D}}$ & $7.4^{\mathrm{BC}}$ \\
Flavor & $5.2^{\mathrm{BC}}$ & $6.1^{\mathrm{AB}}$ & $6.7^{\mathrm{A}}$ & $6.1^{\mathrm{AB}}$ & $6.4^{\mathrm{A}}$ & $4.6^{\mathrm{C}}$ & $4.6^{\mathrm{C}}$ \\
Texture & $7.3^{\mathrm{A}}$ & $7.2^{\mathrm{A}}$ & $7.6^{\mathrm{A}}$ & $7.3^{\mathrm{A}}$ & $7.1^{\mathrm{A}}$ & $5.4^{\mathrm{B}}$ & $5.6^{\mathrm{B}}$ \\
Odor & $6.3^{\mathrm{AB}}$ & $6.6^{\mathrm{A}}$ & $6.8^{\mathrm{A}}$ & $6.1^{\mathrm{ABC}}$ & $6.1^{\mathrm{ABC}}$ & $5.7^{\mathrm{BC}}$ & $5.3^{\mathrm{C}}$
\end{tabular}

${ }^{1}$ Averages followed by the same letter, in each line, do not differ significantly according to the Tukey test, at $5 \%$ probability. The experimental sherbets used in the sensory analysis were: S1 (13.4;58.3;28.3), S2 (15;70;15), S3(20;65;15), S4 (20;45;35), S5 (15;45;40), S6 (5;70;25), and S7(5:55:40), with sugar, milk, and jambolan pulp, respectively. 


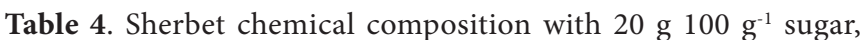

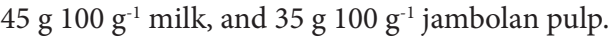

\begin{tabular}{cr}
\hline Chemical compounds & \multicolumn{1}{c}{ Value $^{6}$} \\
\hline Total phenolic compounds (aqueous extract) $^{1}$ & $191.958 \pm 12.5$ \\
Total phenolic compounds (ethanolic extract) $^{139.215 \pm 2.01}$ & $73.00 \pm 2.72$ \\
DPPH inhibition & \\
Anthocyanins $^{3}$ & $51.41 \pm 4.86$ \\
Condensed Tannins & \\
Hydrolyzed Tannins $^{5}$ & $8.0664 \pm 0.65$ \\
\hline
\end{tabular}

${ }^{1} \mathrm{mg}$ of gallic acid g ${ }^{-1} ;{ }^{2} \% ;{ }^{3} \mathrm{mg}$ cyanidin-3-glycoside $100 \mathrm{~g}^{-1} ;{ }^{4} \mathrm{~g}$ of catechin $100 \mathrm{~g}^{-1} ;{ }^{5} \mathrm{mg}$ of gallic acid $100 \mathrm{~g}^{-1} ;{ }^{6}$ average + standard deviation.

4.9 to $6.4 \mathrm{~g} \mathrm{de}_{\mathrm{AG}} 100 \mathrm{~g}^{-1}$. This result indicated the high antioxidant capacity of jambolan sherbet. The high total content of phenolic compounds present in some fruits is related to their antioxidant activity, which provides beneficial health effects, such as the prevention of cancerous diseases (Eichholz et al., 2011).

To eliminate free radicals by the DPPH method, in the jambolan sherbets 73\% of DPP inhibition was found; therefore, these values were similar to the values found by Hwang et al. (2014), who evaluated European blueberry antioxidant activity cultivated in Korea, and obtained 40.6\% DPPH inhibition in extract with $500 \mu \mathrm{g} \mathrm{mL}^{-1}$ concentration.

The anthocyanin content found in the selected jambolan sherbet (Table 4) was lower than that found in the pulp of the same fruit by Vizzotto \& Pereira (2008), who reported 141.8mg of cyanidin-3-glycoside $100 \mathrm{~g}^{-1}$, and by Kuskoski et al. (2006),

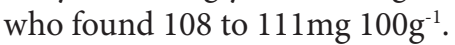

The lower anthocyanin content of the jambolan sherbet in relation to the fruit can be explained by its processing, since this pigment is sensitive to changes in $\mathrm{pH}$, light, temperature, metallic ions, and oxygen (Cavalcanti et al., 2011). Migliato et al. (2007) reported total tannin contents in jambolan fruit of $4.2 \mathrm{~g} 00 \mathrm{~g}^{-1}$, a value considered relatively low by the authors, when compared to other fruits.

In this study, the sum of the hydrolyzed and condensed tannins was $8.2 \%$ higher. For Barcia et al. (2012), who evaluated tannin contents in jambolan fruits from the region of Pelotas, Capão do Leão, and Santa Vitória do Palmar in Brazil, the condensed tannins content ( 14.38 to $35.41 \mathrm{~g}$ catechin $100 \mathrm{~g}^{-1}$ ) was higher than that of the hydrolyzed tannins ( 0.48 to $2.15 \mathrm{~g}$ gallic acid $\left.100 \mathrm{~g}^{-1}\right)$, a tendency that was also observed in this study. This difference between condensed and hydrolyzed tannins positively influenced the sensory aspect, because condensed tannins have a lower protein complexation capacity than hydrolyzed tannins, resulting in low astringency. Tannins possess the property of forming complexes with macromolecules, like proteins and polysaccharides. This complexation probably leads to the formation of a protective layer on the stomach mucosa, making it less permeable and more resistant to chemical or mechanical aggressions (Mello \& Santos, 2004).

Within the search for innovations in the edible ice creams sector, jambolan sherbet is a promising product, because it possesses favorable technological characteristics, coloration, $\mathrm{pH}$, TSS/TA ratio, and sensory acceptance, in addition to low microbiological risk and the significant presence of bioactive compounds, related to its high antioxidant capacity.

\section{Conclusion}

The increase in air incorporation (39.87\%) is related to higher quantities of milk and sugar and lower quantities of jambolan pulp. Higher jambolan pulp contents are related to higher saturation and color intensity, varying between red and blue, since the pulp contains anthocyanic compounds responsible for these colors.

Adding jambolan pulp to the sherbet formulations decreased both TSS/TA and pH because it has acidic characteristics.

The selected formulation was S5, which was accepted by the tasters in relation to all sensory attributes.

The selected sherbet demonstrated high total phenolic compound content. Therefore, it is possible to produce jambolan sherbet with desirable physical, chemical, microbiological, and sensory characteristics and high antioxidant capacity, which could expand the application possibilities of the fruit as an ingredient in the edible ice creams industry.

\section{Acknowledgements}

To CAPES for fellowship support.

\section{References}

American Public Health Association - APHA. (2001). Compendium of methods for the microbiological examination of foods (Vol. 1, 10th ed.). Washington: APHA.

Association of Official Analytical Chemists - AOAC. (1997). Official methods of analysis of AOAC International: agricultural chemicals, contaminants, drugs (Vol. 1, 16th ed.). Gaithersburg: AOAC International.

Ayyanar, M., \& Subash-Babu, P. (2012). Syzygium cumini (L.) skeels: a review of its phytochemical constituents and traditional uses. Asian Pacific Journal of Tropical Biomedicine, 2(3), 240-246. http://dx.doi. org/10.1016/S2221-1691(12)60050-1. PMid:23569906.

Barcia, M. T., Pertuzatti, P. B., Jacques, A. C., Godoy, H. T., \& Zambiari, R. (2012). Bioactive compounds, antioxidant activity and percent composition of jambolão fruits (Syzygium cumini). The Natural Products Journal, 2, 129-138. http://dx.doi.org/10.2174/22103155 11202020129.

Bezerra, M., Araujo, A., Santos, K., \& Correia, R. (2015). Caprine frozen yoghurt produced with fresh and spray dried jambolan fruit pulp (Eugenia jambolana Lam) and Bifidobacterium animalis subsp. lactis BI-07. Lebensmittel-Wissenschaft + Technologie, 62(2), 1099-1104. http://dx.doi.org/10.1016/j.lwt.2015.01.049.

Box, G. E. P., Hunter, W. G., \& Hunter, J. S. (2005). Statistics for experimenters: design, innovation and discovery. Toronto: Wiley.

Brand-Williams, W., Cuvelier, M. E., \& Berset, C. (1995). Use of a free radical method to evaluate antioxidant activity. LebensmittelWissenschaft + Technologie, 28(1), 25-30. http://dx.doi.org/10.1016/ S0023-6438(95)80008-5.

Brune, M., Hallberg, L., \& Skanberg, A. (1991). Determination of ironbinding phenolic groups in foods. Journal of Food Science, 56(1), 128-131. http://dx.doi.org/10.1111/j.1365-2621.1991.tb07992.x. 
Cavalcanti, R. N., Santos, D. T., \& Meireles, M. A. (2011). Non-thermal stabilization mechanisms of anthocyanins in model and food systems-An overview. Food Research International, 44(2), 499-509. http://dx.doi.org/10.1016/j.foodres.2010.12.007.

Cook, K. L. K., \& Hartel, R. W. (2010). Mechanisms of ice crystallization in ice cream production. Comprehensive Reviews in Food Science and Food Safety, 9(2), 213-222. http://dx.doi.org/10.1111/j.15414337.2009.00101.x.

Couto, M. A. L., \& Canniatti-Brazaca, S. G. (2010). Quantification of vitamin $\mathrm{C}$ andantioxidant capacity of citrus varieties. Food Science and Technology, 30, 15-19. http://dx.doi.org/10.1590/S010120612010000500003.

Eichholz, I., Huyskens-keil, S., Keller, A., Ulrich, D., Kroh, L. W., \& Rohn, S. (2011). UV-B-induced changes of volatile metabolites and phenolic compounds in blueberries (Vaccinium Corymbosum L.). Food Chemistry, 126(1), 60-64. http://dx.doi.org/10.1016/j. foodchem.2010.10.071.

Fagnani, R., Schuck, J., Botaro, B. G., \& Santos, F. C. (2017). Extended storage of cold raw milk on yogurt manufacturing. Pesquisa Agropecuária Brasileira, 52(2), 104-112. http://dx.doi.org/10.1590/ s0100-204x2017000200004.

Fanin, F. C., \& Saracchi, P. A. (2006). Tecnologia de gelados comestíveis. (2nd ed.). São Paulo: Senai-SP.

Hansen, D. D. S., Silva, S. A., Fonseca, A. A. O., Hansen, O. A. D. S., \& França, N. O. (2008). Caracterização química de frutos de jenipapeiros nativos do Recôncavo Baiano visando ao consumo natural e industrialização. Revista Brasileira de Fruticultura, 30(4), 964-969. http://dx.doi.org/10.1590/S0100-29452008000400021.

Hwang, S. J., Yoon, W. B., Lee, O. H., Cha, S. J., \& Kim, J. D. (2014). Radical-scavenging-linked antioxidant activities of extracts from black chokeberry and blueberry cultivated in Korea. Food Chemistry, 146, 71-77. http://dx.doi.org/10.1016/j.foodchem.2013.09.035. PMid:24176315.

Kapoor, S., \& Ranote, P. S. (2015). Antioxidant potentials and quality of blended pear-jamum (Syzygium cumini L.) juice. International Research Journal of Biological Sciences, 4, 30-37.

Kuskoski, E. M., Asuero, A. G., Morales, M. T., \& Fett, R. (2006). Frutos tropicais silvestres e polpas de frutas congeladas: atividade antioxidante, polifenóis e antocianinas. Ciência Rural, 36(4), 12831287. http://dx.doi.org/10.1590/S0103-84782006000400037.

Lago, E. S., Gomes, E., \& Silva, R. (2006). Production of jambolan (Syzygium cumini Lamarck) jelly: processing, physical-chemical properties and sensory evaluation. Food Science and Technology, 26, 847-852. http://dx.doi.org/10.1590/S0101-20612006000400021.

Lee, J., Durst, R. W., \& Wrolstad, R. E. (2005). Determination of total monomeric anthocyanin pigment content of fruit juices, beverages, natural colorants, and wines by the $\mathrm{pH}$ differential method: collaborative study. Journal of AOAC International, 88(5), 12691278. PMid:16385975.

Marshall, R. T., \& Arbuckle, W. S. (1996). Ice cream (5th ed.). New York: Chapman \& Hall. http://dx.doi.org/10.1007/978-1-4613-0477-7.

Marshall, R. T., Goff, H. D., \& Hartel, R. W. (2003). Ice cream (6th ed.). New York: Kluwer Academic Publishers. http://dx.doi. org/10.1007/978-1-4615-0163-3.

Martinou-Voulasiki, I. S., \& Zerfiridis, G. K. (1990). Effect of some stabilizers on texture and sensory characteristics of yogurt ice cream from sheep's milk. Journal of Food Science, 55(3), 703-707. http:// dx.doi.org/10.1111/j.1365-2621.1990.tb05211.x.

Mello, J. C. P., \& Santos, S. C. (2004). Taninos. In: C. M. O. Simões, E. P. SchenkeL, G. Gosmann, J. C. P. Mello, L. A. Mentz, \& P.R. Petrovick (Eds.), Farmacognosia: da planta ao medicamento (pp. 615-656). Porto Alegre: Editora da UFRGS.

Migliato, K. F., Moreira, R. R. D., Mello, J. C. P., Sacramento, L. V. S., Correa, M. A., \& Salgado, H. R. N. (2007). Controle da qualidade do fruto de Syzygium cumini L. Skeels. Revista Brasileira de Farmacognosia, 1(1), 94-101. http://dx.doi.org/10.1590/S0102-695X2007000100018.

Mussi, L. P., Guimarães, A. O., Ferreira, K. S., \& Pereira, N. R. (2015). Spouted bed drying of jambolão (Syzygium cumini) residue: drying kinetics and effect on the antioxidant activity, anthocyanins and nutrients contents. Lebensmittel-Wissenschaft + Technologie, 61(1), 80-88. http://dx.doi.org/10.1016/j.lwt.2014.11.040.

Oliveira, A. L., Silva, M. G. F., Sobral, P. J. A., Oliveira, C. A. F., \& Habitante, A. M. Q. B. (2005). Physical properties of mixes to mangaba sherbet. Brazilian Agricultural Research Corporation, 40, 581-586.

Price, M. L., Van Scoyoc, S., \& Butler, L. G. (1978). A Critical Evaluation of the Vanillin Reaction as an Assay for Tannin in Sorghum Grain. Journal of Agricultural and Food Chemistry, 26(5), 1214-1218. http:// dx.doi.org/10.1021/jf60219a031.

Reynertson, K. A., Yang, H., Jiang, B., Basile, M. J., \& Kennelly, E. J. (2008). Quantitative analysis of antiradical phenolic constituents from fourteen edible Myrtaceae fruits. Food Chemistry, 109(4), 883-890. http://dx.doi.org/10.1016/j.foodchem.2008.01.021. PMid:21340048.

Stone, H., \& Sidel, J. L. (2004). Sensory evaluation practices. San Diego: Elsevier.

Vizzotto, M., \& Pereira, M. C. (2008). Caracterização das propriedades funcionais do jambolão. Boletim de Pesquisas e Desenvolvimento. Pelotas: Embrapa Clima Temperado.

Waterhouse, A. L. (2002). Polyphenolics: determination of total phenolics. In R. E. Erolstad (Ed.), Current protocols in food analytical chemistry (Chap. 1.1, pp. 1.1.1-1.1.8). New York: John Wiley \& Sons.

Yi, Akoh, C. C., Fischer, J., \& Krewer, G. (2006). Effects of phenolic compounds in blueberries and muscadine grapes on HepG2 cell viability and apoptosis. Food Research International, 39(5), 628-638. http://dx.doi.org/10.1016/j.foodres.2006.01.001. 